MINI REVIEW

\title{
Antitumor properties and toxicity effects of Peganum harmala L. (Zygophyllaceae)
}

\author{
Fatima Lamchouri
}

\begin{abstract}
Peganum harmala L. (Zygophylaceae) is a medicinal plant known to possess hypothermic and hallucinogenic properties from ancient times. Though the alkaloids identified from the species showed extensive pharmacological actions, they are highly cytotoxic. The present review summarises important findings on the antitumor properties and toxicity effects of the chemical constituents of $P$. harmala.
\end{abstract}

Keywords: Peganum harmala; medicinal plant; antitumor; toxicity

Peganum harmala L. (Zygophylaceae) is a perennial shrub growing up to $1 \mathrm{~m}$ tall. The seeds of $P$. harmala contain about 2-6\% pharmacologically active alkaloids (Hilal \& Young ken, 1983), which are mostly b-carbolines such as harman, harmine, harmaline, and harmalol (El-Rifaie, 1980; Kartal, Altun, \& Kurucu, 2003). Seeds and roots contained the highest levels of alkaloids with low levels in stems and leaves, and absent in flowers. Harmine and harmaline accumulated in dry seeds at $4.3 \%$ and $5.6 \%$ $(\mathrm{w} / \mathrm{w})$, respectively, harmalol at $0.6 \%$, and tetrahydroharmine at $0.1 \%(\mathrm{w} / \mathrm{w})$. Roots contained harmine and harmol with $2.0 \%$ and $1.4 \%(\mathrm{w} / \mathrm{w})$, respectively (Herraiz, González, Ancín-Azpilicueta, Arán, \& Guillén, 2010). In traditional medicine, P. harmala has

Received: 27 June 2014 / Accepted revised version: 22 July 2014 / Published online: 02 October 2014

(C) Horizon e-Publishing Group

CITATION

Lamchouri, F. (2014). Antitumor properties and toxicity effects of Peganum harmala L. (Zygophyllaceae). Plant Science Today, 1(4), 192-195. http://dx.doi.org/10.14719/pst.2014.1.4.71

\section{AUTHOR'S AFFILIATION}

Faculté Polydisciplinaire de Taza, Université Sidi Mohamed Ben Abdellah, Morocco. Equipe de Recherche: "Substances Naturelles \& Environnement"

CORRESPONDENCE

凶Pr. Fatima Lamchouri, e-mail: fatima.lamchouri@gmail.com been used to treat coughs, hypertension, diabetes, asthma, jaundice, lumbago, and many other human ailments (Riba et al., 2003; Tahraoui, El-Hilaly, Israili, \& Lyoussi, 2007). Its seeds were known to possess hypothermic, and essentially hallucinogenic properties. Many studies have been conducted on the antibacterial, antifungal, antiviral and antitumour effects of $P$. harmala seeds. In Moroccan traditional medicine, seed powder is sometimes used on skin and subcutaneous tumours.

The alkaloids identified from the plants of the genus Peganum showed extensive pharmacological actions, such as antitumor effects (Jahaniani, Ahmed Ebrahimi, Rahbar-Roshandel, \& Mahmoudian, 2005), analgesic effects (Farouk, Laroubia, Aboufatimaa, Benharref, \& Chait, 2008), vasorelaxant activities (Astulla et al., 2008), antimicrobial activity (Prashanth \& John, 1999; Arshad, Zitterl-Eglseer, Hasnain, \& Hess, 2008), strong reversible inhibition of monoamine oxidase (Kim, Sablin, \& Ramsay, 1997; Schwarz, Houghton, Rose, Jenner, \& Lees, 2003), and inhibitive activity against acetylcholinesterase (Zheng, Youdim, \& Fridkin, 2009). In the past decades, more attention has been drawn on their anticancer potencies (Boeira, da Silva, Erdtmann, \& Henriques, 2001; Go“ckler et al., 2009; Adhami, Farsam, \& Krenn, 2011). Recently, pharmacological and therapeutic effects of P. harmala and its main alkaloids have been reviewed (Moloudizargari, Mikaili, Aghajanshakeri, Asghari, \& Shayegh, 2013). The present attempt aims to review the antitumor properties and toxicity effects of chemical constituents of $P$. harmala.

P. harmala is a plant known since the first century A.D. and is still used for therapeutic purposes. Harmaline, the active principle of the plant seeds, and its derivatives, cause visual troubles, loss of coordination, agitation and delirium, and, at high doses, it can produce paralysis (Lamchouri et al., 2002). In a study designed to investigate some aspects of the antineoplastic properties of the $P$. harmala, varying concentrations of total alkaloid extracts of its seeds were tested in vitro on four tumoural cell-lines (Lamchouri et al., 1999). Results obtained indicate that alkaloids of Peganum have high cell toxicity in vitro. The 
active principle present in the plant extract at a dose of 50 $\mathrm{mg} / \mathrm{kg}$ given orally to mice for 40 days was found to have significant antitumoural activity. P. harmala alkaloids thus possess significant antitumour potential, which could prove useful as a novel anticancer therapy. Subsequently, many studies show that the alkaloidal extract of $P$. harmala seeds is cytotoxic to several murine cell lines including UCP-Med and Med-mek carcinoma, and UCP-Med sarcoma in vitro and has an antitumor effect in a tumor model in vivo (Lamchouri et al., 2000; Lamchouri, 2000). Tumor proliferation was significantly reduced with $P$. harmala extracts (Lamchouri et al., 2000).

In another interesting study aimed at evaluating the use and manipulation of therapeutic doses of aqueous extract of $P$. harmala, Wistar rats were orally dosed acutely and the $\mathrm{LD}_{50}$ obtained was $2.70+/-0.05 \mathrm{~g} / \mathrm{kg}$ (Lamchouri et al., 2002). In chronic studies aqueous extract of $P$. harmala administered orally for six times a week at doses of $1,1.35$ and $2 \mathrm{~g} / \mathrm{kg}$ during 3 month period increased transaminases. Changes in glucose and creatinine were not significant. No significant gross changes were found at necropsy. Histologic study showed liver degeneration and spongiform changes in the central nervous system (CNS) in rats treated with $2 \mathrm{~g} / \mathrm{kg}$ dose but not at the therapeutic dose of $1 \mathrm{~g} / \mathrm{kg}$.

The $\beta$-carboline alkaloids present in medicinal plants like $P$. harmala have recently drawn attention due to their antitumor properties. Recently, in an attempt to discover novel b-carboline alkaloids with potent antitumor activity and low neurotoxicity, nine harmine derivatives were investigated for their antitumor effects and acute toxicities in mice, and structure-activity relationship (SAR) analysis (Rihui et al., 2004 ; Qi et al., 2004). In their study, nine harmine derivatives (including harmine) were investigated for their potential cytotoxicities against human $\mathrm{HepG}_{2}$ cells using 3-(4,5-dimethylthiazol-2-yl)-2,5diphenyltetrazolium bromide (MTT) assays. The harmine and its derivatives resulted in in vitro cytotoxicity ( $\left.\mathrm{IC}_{50}\right)$ values of $0.011-0.021 \mathrm{lmol} / \mathrm{ml} \mathrm{HepG}_{2}$ cells.

To recognize the structure-activity relationships, the molecular structures of the series of nine harmine derivatives (including harmine) have been studied. The tumor inhibition rates of harmine derivatives in mice bearing Lewis lung cancer, sarcoma180, or HepA tumor shows that harmine has only moderate antitumor effect, yet some of the derivatives showed inhibition rates of more than $40 \%$ while few others exhibited the highest antitumor effect among these compounds. It appears that both short alkyl and aryl substitution at R9 is favourable for antitumor activity, but aryl substitution is more favourable. The SAR analysis indicated that the formate substitution at R3 of the tricyclic skeleton reduced their neurotoxicity, while the short alkyl or aryl substitution at R9 increased the antitumor activity. All these findings indicate that compounds with both substitutions at R3 and R9 have high antitumor activity and low toxicity (Qi et al., 2004).

The antiproliferative activity of four alkaloids harmalacidine, harmine, peganine, and vasicinone isolated from $P$. harmala seeds and theirs computational study was investigated by Lamchouri, Toufik, Bouzzine, Hamidi, \& Bouachrine (2010). These compounds were assayed in vitro for their effect on thymidine incorporation using Jurkat leukemia cell line at concentration of 5, 10, 25, 50, and $100 \mathrm{lg} / \mathrm{ml}$. Their cytotoxicity was also evaluated at the concentrations indicated above on Sp2/0-Ag14 myeloma cells, Med-mek carcinoma, UCP-med Carcinoma, and UCP-med sarcoma. Results showed that vasicinone, harmine, and harmalacidine inhibited the proliferation of Jurkat, clone E6-1 cell line with significant cytotoxic effect. No noticeable effect of peganine on thymidine incorporation was observed. These in vitro studies have shown that harmine, b-carbolines alkaloid have more activity (Lamchouri et al., 2010). The harmine and $\beta$-carbolines alkaloid are highly cytotoxic and significantly inhibited tumor cell growth with apoptotic effect (Hamsa \& Kuttan, 2011). This study showed that harmine significantly inhibited tumor nodule formation in the lung tissue and decreased various biochemical parameters associated with lung metastasis.

In order to identify the components in the seed extract of $P$. harmala responsible for the cytotoxic effects, four alkaloids: harmalicidine, harmine, peganine (vasicine) and vasicinone were isolated (Lamchouri et al., 2013). The study also focused on the cytotoxic and antiproliferative activity of the isolated alkaloids and total alkaloidal fraction (TAF) in several tumor cell lines. The alkaloids and TAF inhibited the growth of tumor cell lines to varying degrees. Of the substances evaluated, harmine was the most active compound ( $\mathrm{C}_{50}$ for the 4 tumor cell lines varying between $2.43 \mu \mathrm{g} / \mathrm{ml}$ and $18.39 \mu \mathrm{g} / \mathrm{mL}$ ), followed by TAF (range of IC50 = $7.32 \mu \mathrm{g} / \mathrm{mL}$ to $13.83 \mu \mathrm{g} / \mathrm{mL}$ ); peganine was the least active $\left(\mathrm{IC}_{50}=50 \mu \mathrm{g} / \mathrm{mL}\right.$ to $>100$ $\mu \mathrm{g} / \mathrm{ml}$ ). In terms of antiproliferative effect, vasicinone and TAF were more potent than other substances: the concentration of vasicinone, and TAF needed to inhibit the incorporation of $\{3 \mathrm{H}-\mathrm{TDR}\}$ in the DNA cells of Jurkat, E6-1 clone by $50 \%\left(\mathrm{IC}_{50}\right)$ were $8.60 \pm 0.023 \mu \mathrm{g} / \mathrm{mL}$ and $8.94 \pm$ $0.017 \mu \mathrm{g} / \mathrm{mL}$, respectively, while peganine was the least active $\left(\mathrm{IC}_{50}>100 \mu \mathrm{g} / \mathrm{mL}\right)$. The $\mathrm{IC}_{50}$ values for harmalacidine $(27.10 \pm 0.011 \mu \mathrm{g} / \mathrm{mL})$ and harmine (46.57 $\pm 0.011 \mu \mathrm{g} / \mathrm{mL}$ ) were intermediate. The harmala alkaloids inhibited the growth of four tumor cell lines, and proliferation of Jurkat cells with varying potencies. Harmine was the most potent in inhibiting cell growth, and vasicinone was most active as antiproliferating substance. The TAF had significant cytotoxic as well as antiproliferating activity. 
It is well known that alkaloids from P. harmala inhibited the growth of tumor cell lines but a study conducted in China revealed that total alkaloids from seeds of $P$. harmala possessed significant growth inhibitory effect on plants (Shao, Huang, Zhang, \& Zhang, 2013). Harmaline exerted potent inhibitory effects on seedling growth of treated plants, especially dicots, inhibiting root elongation of lettuce and amaranth by $31 \%$ and $47 \%$ at a very low concentration $(5 \mu \mathrm{g} / \mathrm{mL})$, whereas harmine exhibited much weaker non-selective inhibitory effect on the plants. Considering the high yield and poor utilization of $P$. harmala in China, it is anticipated that this plant could be exploited as an alternative weed management tool in the future. In another study, the leaf extract and its fractions of $P$. harmala have shown pronounced mortal effect, decreased percent pupation and adult emergence of the cotton leaf worm, Spodoptera littoralis Boisd (Shonouda, Osman, Salama, \& Ayoub, 2008). The medicinal plant $P$. harmala could be carefully applied in integrated pest management due to its strong effect on cotton leaf worm pest. Interestingly, a novel protein extracted from $P$. harmala inhibited growth of fungi such as Alternaria alternate, Penicillium degitatum, Rhizopus stuolonifer, and Magnaporthe grisea, and its antifungal activity was stable in the temperature range $4-60^{\circ} \mathrm{C}$, and in the $\mathrm{pH}$ range $4-10$ (Ma et al., 2013).

In a recent study (Daoud, Song, Xiao, \& Shang, 2014), B-9-3, a semi-synthetic derivative of $B$-carboline that is formed of two harmane molecules bound by a butyl group, exhibited anti-proliferative effect against a human lung cancer cell line, a human breast cancer cell line, and a human colorectal carcinoma cell line via induction of apoptosis and inhibition of cell migration. Moreover, B-9-3 inhibited tube formation in human umbilical vascular endothelial cell line (HUVEC), which indicates an anti-angiogenesis activity in vitro. Earlier molecular docking studies (Misra et al., 2008) suggest that a binding interaction with DNA topoisomerase I of Leishmania donovani (binding energy of $-79 \mathrm{kcal} / \mathrm{mol}$ ) forms a stable complex, indicating a possible role in apoptosis.

In conclusion, alkaloids from $P$. harmala show strong antitumor properties and in the mean time exhibited acute toxicity. Hence, one must be careful while using the seed extracts for traditional medicinal preparations and for any drug development programmes. In the mean time, it is to be noted that there is evidence for anti oxidative efficacy of P. harmala (Soliman, Abu-El-Zahab, \& Alswiai, 2013; Khlifi et al., 2013). Analysis of purified protein from seeds of $P$. harmala plant against carbon tetrachloride $\left(\mathrm{CCl}_{4}\right)$ induced oxidative stress in rats showed strong antioxidant activity (Soliman et al., 2013). Further, considering the increased rate of environmental pollution, contaminants such as dioxins are very prevalent on the environment that have been linked with a variety of deleterious effects on human health including increased cancer rates. Studies proved that P. harmala is a candidate herbal plant for preventing dioxin mediated effects (El Gendy, Somayaji, \& El-Kadi, 2010).

\section{References}

Adhami, H. R., Farsam, H., \& Krenn, L. (2011). Screening of Medicinal Plants from Iranian Traditional Medicine for Acetylcholinesterase Inhibition. Phytotherapy Research, 25, 1148. http://dx.doi.org/10.1002/ptr.3409 PMid:21287652

Arshad, N., Zitterl-Eglseer, K., Hasnain, S., \& Hess, M. (2008). Effect of Peganum harmala or its ß-carboline alkaloids on certain antibiotic resistant strains of bacteria and protozoa from poultry. Phytotherapy Research, 22, 1533. http://dx.doi.org/10.1002/ptr.2528 PMid:18814210

Astulla, A., Zaima, K., Matsuno, Y., Hirasawa, Y., Ekasari, W., Widyawaruyanti, A., ... \& Morita, H. (2008). Alkaloids from the seeds of Peganum harmala showing antiplasmodial and vasorelaxant activities. Journal of Natural Medicines 62, 470 http://dx.doi.org/10.1007/s11418-008-0259-7 PMid:18523842

Boeira, J. M., da Silva, J., Erdtmann, B., \& Henriques, J. A. P. (2001). Genotoxic Effects of the Alkaloids Harman and Harmine Assessed by Comet Assay and Chromosome Aberration Test in Mammalian Cells in vitro. Pharmacology \& Toxicology, 89, 287. PMid:11903953 http://dx.doi.org/10.1034/j.1600-0773.2001.d01-162.x

Daoud, A., Song, J., Xiao, F., \& Shang, J. (2014). B-9-3, a novel ß-carboline derivative exhibits anti-cancer activity via induction of apoptosis and inhibition of cell migration in vitro. European Journal of Pharmacology, 724, 219-230. http://dx.doi.org/10.1016/j.ejphar.2013.12.038

El Gendy, M. A., Somayaji, V., \& El-Kadi, A. O. (2010). Peganum harmala $\mathrm{L}$. is a candidate herbal plant for preventing dioxin mediated effects. Planta Medica, 76(7), 671-7. http://dx.doi.org/10.1055/s-0029-1240633

El-Rifaie, M. E.-S. (1980). Peganum harmala. International Journal of Dermatology, 19, 221-222. http://dx.doi.org/10.1111/j.1365-4362.1980.tb00305.x

Farouk, L., Laroubia, A., Aboufatimaa, R., Benharref, A., \& Chait, A. (2008). Evaluation of the analgesic effect of alkaloid extract of Peganum harmala L.: Possible mechanisms involved. Journal of Ethnopharmacology, 115, 449-454. PMid:18054186 http://dx.doi.org/10.1016/i.jep.2007.10.014

Go"ckler, N., Jofre, G., Papadopoulos, C., Soppa, U., Tejedorand, F. J., \& Becker, W. (2009). Harmine specifically inhibits protein kinase DYRK1A and interferes with neurite formation. FEBS Journal, 276, 6324. http://dx.doi.org/10.1111/i.1742-4658.2009.07346.x PMid:19796173

Hamsa, T. P., \& Kuttan, G. (2011). Harmine activates intrinsic and extrinsic pathways of apoptosis in B16F-10 melanoma. Chinese Medicine, 6, 11. http://dx.doi.org/10.1186/1749-8546-6-11 PMid:21429205 PMCid:PMC3076298

Herraiz, T., González, D., Ancín-Azpilicueta, C., Arán, V. J., \& Guillén, H. (2010). $\beta$-Carboline alkaloids in Peganum harmala and inhibition of human monoamine oxidase (MAO). Food and Chemical Toxicology, 48(3), 839-45. http://dx.doi.org/10.1016/j.fct.2009.12.019

Hilal, A. H. S., \& Young ken, H. W. (1983). Certain poisnous plants of Egypt. Pharmaceutical society of Egypt, Ed. Dokki. The 
national information and Documentation centre, Cairo, Egypt.

Jahaniani, F., Ahmed Ebrahimi, S., Rahbar-Roshandel, N. \& Mahmoudian, M. (2005). Xanthomicrol is the main cytotoxic component of Dracocephalum kotschyii and a potential anti-cancer agent. Phytochemistry 66, 1581-1592. http://dx.doi.org/10.1016/j.phytochem.2005.04.035 PMid:15949825

Kartal, M., Altun, S., \& Kurucu, S. (2003). HPLC method for the analysis of harmol, harmalol, harmine and harmaline in the seeds of Peganum harmala L. Journal of Pharmaceutical and Biomedical Analysis, 31, 263. http://dx.doi.org/10.1016/S0731-7085(02)00568-X

Khlifi, D., Sghaier, R. M., Amouri, S., Laouini, D., Hamdi, M., \& Bouajila, J. (2013). Composition and anti-oxidant, anti-cancer and anti-inflammatory activities of Artemisia herba-alba, Ruta chalpensis L. and Peganum harmala L. Food and Chemical Toxicology, 55, 202-208. http://dx.doi.org/10.1016/i.fct.2013.01.004

Kim, H., Sablin, S. O., \& Ramsay, R. R. (1997). Inhibition of Monoamine Oxidase A by ß-Carboline Derivatives. Archives of Biochemistry and Biophysics, 337, 137 http://dx.doi.org/10.1006/abbi.1996.9771 PMid:8990278

Lamchouri, F. (2000). Thèse de Doctorat Es-sciences Physiologie-Pharmacologie, Maroc.

Lamchouri, F., Settaf, A., Cherrah, Y., El Hamidi, M., Tligui, N. S., Lyoussi, B., \& Hassar, M. (2002). Experimental toxicity of Peganum harmala seeds. Annales Pharmaceutiques Françaises, 60, 123. PMid:11976557

Lamchouri, F., Settaf, A., Cherrah, Y., Hassar, M., Zemzami, M., Atif, N., ... \& Lyoussi, B. (2000). In vitro cell-toxicity of Peganum harmala alkaloids on cancerous cell-lines. Fitoterapia 71, 50. http://dx.doi.org/10.1016/S0367-326X(99)00117-3

Lamchouri, F., Settaf, A., Cherrah, Y., Zemzami, M., B. Lyoussi, A. Zaid, ... Hassar M. (1999). Antitumor principles from Peganum harmala seeds. Therapie, 54, 753-758. PMid:10709452

Lamchouri, F., Toufik, H., Bouzzine, S. M., Hamidi, M., \& Bouachrine, M. (2010). Experimental and computational study of biological activities of alkaloids isolated from Peganum harmala seeds. Journal of Materials and Environmental Science, 1, 343.

Lamchouri, F., Zemzami, M., Jossang, A., Settaf, A., Israili, Z. H., \& Lyoussi, B. (2013). Cytotoxicity of alkaloids isolated from Peganum harmala seeds. Pakistan Journal of Pharmaceutical Sciences, 26(4), 699-706. PMid:23811445

Ma, X., Liu, D., Tang, H., Wang, Y., Wu, T., Li, Y., ... \& Zhang, F. (2013). Purification and characterization of a novel antifungal protein with antiproliferation and anti-HIV-1 reverse transcriptase activities from Peganum harmala seeds. Acta Biochimica et Biophysica Sinica (Shanghai), 45(2), 87-94. http://dx.doi.org/10.1093/abbs/gms094

Misra, P., Khaliq, T., Dixit, A., SenGupta, S., Samant, M., Kumari, S., ... Dube, A. (2008). Antileishmanial activity mediated by apoptosis and structure-based target study of peganine hydrochloride dihydrate: an approach for rational drug design. Journal of Antimicrobial Chemotherapy, 62(5), 998-1002. http://dx.doi.org/10.1093/jac/dkn319

Moloudizargari, M., Mikaili, P., Aghajanshakeri, S., Asghari, M. H., \& Shayegh, J. (2013). Pharmacological and therapeutic effects of Peganum harmala and its main alkaloids. Pharmacognosy Reviews, 7, 199-212. Available from: http://www.phcogrev.com/text.asp?2013/7/14/199/120524

Prashanth, D., \& John, S. (1999). Antibacterial activity of Peganum harmala. Fitoterapia $70, \quad 438$. http://dx.doi.org/10.1016/S0367-326X(99)00065-9

Qi, C., Rihui, C., Hongsheng, C., Xuerui, H., Huifang, Y., Shufeng, Z. \& $\mathrm{Xu}, \mathrm{A}$. (2004). Antitumor and neurotoxic effects of novel harmine derivatives and structure-activity relationship analysis. International Journal of Cancer, 114, 675-682. http://dx.doi.org/10.1002/ijc.20703

Riba, J., Valle, M., Urbano, G., Yritia, M., Morte, A., \& Barbanoj, M. J. (2003). Human Pharmacology of Ayahuasca: Subjective and Cardiovascular Effects, Monoamine Metabolite Excretion, and Pharmacokinetics. The Journal of Pharmacology and Experimental Therapeutics, 306, 73. PMid:12660312 http://dx.doi.org/10.1124/jpet.103.049882

Rihui, C., Qi, C., Xuerui, H., Hongsheng, C., Huaji, G., Yan, M., ... \& Anlong, X. (2004). Synthesis, acute toxicities, and antitumor effects of novel 9-substituted ß-carboline derivatives. Bioorganic \& Medicinal Chemistry, 12, 4613-4623. http://dx.doi.org/10.1016/i.bmc.2004.06.038 PMid:15358288

Schwarz, M. J., Houghton, P. J., Rose, S., Jenner, P., \& Lees, A. D. (2003). Activities of extract and constituents of Banisteriopsis caapi relevant to parkinsonism. Pharmacology Biochemistry and Behavior, 75, 627. http://dx.doi.org/10.1016/S0091-3057(03)00129-1

Shao, H., Huang, X., Zhang, Y., \& Zhang, C. (2013). Main alkaloids of Peganum harmala L. and their different effects on dicot and monocot crops. Molecules, 18(3), 2623-34. http://dx.doi.org/10.3390/molecules18032623

Shonouda, M., Osman, S., Salama, O., \& Ayoub, A. (2008). Toxical effect of Peganum harmala L. leaves on the cotton leaf worm, Spodoptera littoralis Boisd and its parasitoids Microplitis rufiventris Kok. Pakistan Journal of Biological Sciences, 11(4), 546-52. PMid:18817124. http://dx.doi.org/10.3923/pjbs.2008.546.552

Soliman, A. M., Abu-El-Zahab, H. S., \& Alswiai, G. A. (2013). Efficacy evaluation of the protein isolated from Peganum harmala seeds as an antioxidant in liver of rats. Asian Pacific Journal of Tropical Medicine, 6(4), 285-95. http://dx.doi.org/10.1016/S1995-7645(13)60058-9

Tahraoui, A., El-Hilaly, J., Israili, Z. H., \& Lyoussi. B. J. (2007). Ethnopharmacological survey of plants used in the traditional treatment of hypertension and diabetes in south-eastern Morocco (Errachidia province). Journal of Ethnopharmacology, 110, 105. PMid:17052873 http://dx.doi.org/10.1016/i.jep.2006.09.011

Zheng, H., Youdim, M. B. H., \& Fridkin, M. J. (2009). Site-Activated Multifunctional Chelator with Acetylcholinesterase and Neuroprotective-Neurorestorative Moieties for Alzheimer's Therapy. Journal of Medicinal Chemistry, 52, 4095. http://dx.doi.org/10.1021/jm900504c PMid:19485411

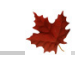

